\title{
Perspectives on the Belhar Confession
}

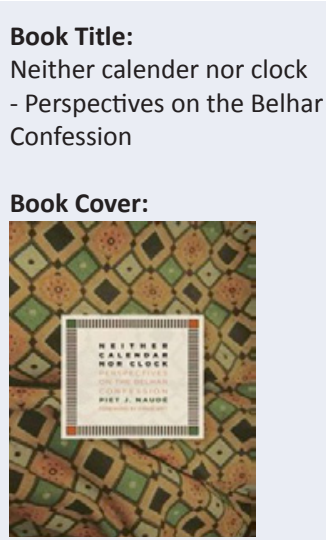

Author:

Piet J. Naudé

ISBN:

978-0-8028-6259-4

Publisher:

William B. Eerdmans, Grand

Rapids, 2010, 255 p., $£ 17.27^{*}$

*Book price at time of review

-

Review Title:

Perspectives on the Belhar

Confession

\section{Reviewer:}

Danie Veldsman ${ }^{1}$

\section{Affiliation:}

${ }^{1}$ Department of Dogmatics,

University of Pretoria, South Africa

Email:

Danie.veldsman@up.ac.za

Postal address:

Private Bag X20, Hatfield,

Pretoria 0028, South Africa

How to cite this book

review:

Veldsman, D., 2012,

'Perspectives on the Belhar Confession', Verbum et

Ecclesia 33(1), Art. \#678,

2 pages. http://dx.doi.

org/10.4102/ve.v33i1.678

(C) 2012. The Authors.

Licensee: AOSIS

OpenJournals. This work

is licensed under the

Creative Commons

Attribution License.
The interesting title of Neither calendar nor clock comes from the German-Swiss theologian Karl Barth's Church Dogmatics. This title was used in reference to the moment of confession, stating that it is bound to neither calendar nor clock, but when its hour for the church comes, it may and must occur. Most surely this has been the very same driving force (must occur!) behind the writing of a very timely book on the Belhar Confession by Naudé, professor of Ethics and Director of the Business School at the Nelson Mandela Metropolitan University, Port Elizabeth, South Africa. Must and had occured, since the Belhar Confession has since its birth as Reformed confessional document during the church and theological struggles in Apartheid South Africa during the 1980s unleashed in its historical-theological wake strong repercussions across the ecclesial and political spectrum. Naudé explicitly qualifies his own must occur, saying that an important motive behind his book was to place this beautiful African confession in the global arena and to invite theological reflection from others. Even more, it was not done for the sake of Belhar as such, but rather for the truth of the gospel, to which Belhar witnessed and is still witnessing today. This he has done exceptionally well in his thorough analysis and explicating of the historical and theological-confessional significance of Belhar and its ongoing wider ecumenical implications and challenges.

Four parts make up Naudé's exposition, namely:

1. Tradition (Part 1 )

2. Confession (Part 2)

3. Reception (Part 3)

4. Contemporary significance (Part 4).

In Tradition, which consists of two chapters, he firstly analyses Belhar's 'no', explaining against a condensed account of South Africa's theological history (Kuyper and Jonker's criticism, Warneck, Pietism), what was rejected at the time and why. As protest confession, Belhar - and its Accompanying Letter - speaks from a confessing tradition against a false representation of the gospel. Secondly he situates the confession within the historical framework of preceding ecumenical witnesses (between 1948 and 1982) as countervoices against apartheid theology, namely the Cottesloe Declaration of 1961 and the Message of the People of 1968. In the two chapters of the next part, Confession, he focuses on the core criteria for church confessions as explicated by Barth, arguing that Belhar represents a legitimate confession. He subsequently explores Belhar's relation with the oldest ecumenical creed (Nicene-Constantinopolitan Creed) as adopted in 381, demonstrating that Belhar, for him indeed, witnesses to the same apostolic faith as handed down in the church through the ages. In the second part, Reception, he highlights the ecumenical challenges posed by the confession, and then continues to draw in broad outlines of the reception process outside South Africa and in the Dutch Reform Church. He thereafter considers the strong links between Belhar and a variety of ecumenical initiatives, mainly stemming from the World Council of Churches. In the last three chapters of the fourth part, Contemporary significance, he addresses contemporary challenges that have been raised in the wake of the Belhar story, namely the call to embody unity in freedom, to practice reconciliation and to pursue justice. These are presented as examples of creative rereadings of the Belhar with the purpose of speaking into the 21st century.

Naude does not pretend in his Neither calendar nor Clock to speak a final word on Belhar. Instead, Belhar and more than Belhar comes into play, presenting the reader with a deep thought provoking theological exercise in confessional discernment of the incarnated truth of the gospel message. In his foreword to the book, the Stellenbosch systematic theologian Dirkie Smit captures this significance well, saying that Naudé does not provide solutions, but rather demonstrates how historical decisions and commitments, voices from moments in history, can remain inspiring today, calling, claiming, challenging us to discern the spirit of our times, to read our moment in history, to recognise the temptations for our church, the threats to our proclamation of the gospel. He furthermore states that not everyone will agree with his analyses and positions. For 
Smit, however, the orientating potential of the confessional tradition does not lie in the speaking of final words but in opening our eyes, hearts, and minds to speak and search together and discern together, and to act on this. Naudé had succeeded in an exemplary manner so that one can hope with him (see page xvii) that his book will assist at a theological level in moving toward a positive and full reception of Belhar in a reunited South African Reformed Church. If the book's academic acclaim is anything to go on, having been awarded the Andrew Murray-Desmond Tutu Prize in May 2011, an acknowledging thrust has been given to this ongoing process as task.

The book comprises in closing four Appendixes, namely, (1) The Belhar Confession (1982), (2) Nicene Creed (381), (3) Cottesloe Declaration (1961) and (4) Message to the People of South Africa (1968); a bibliography and Index. 